\title{
Screening of Some Selected Teff Varieties/Lines for Their Salt Stress Tolerance
}

\author{
Birhane Hailu, Hagos Mehari and Abeba Tesfay \\ Ethiopian Institute of Agricultural Research, Mekhoni Agricultural Research Center, Mekhoni, Ethiopia.
}

\begin{abstract}
Salinity is one of the major environmental problem that lead to deterioration of agricultural land and, as a result, to reduction in crop productivity. This research tested to evaluate and identify salinity stress tolerant Teff varieties/lines and to determine the effect of salinity at different levels of $\mathrm{NaCl}$. The screening procedures were conducted at three growth stages; germination, seedling and field experiment. Experimental treatment included 3 levels of $\mathrm{NaCl}(0,10$ and $15 \mathrm{dS} \mathrm{m}-1)$ at germination and seedling stages. Results indicated that, all investigated traits were affected by salt stress at germination and seedling stages. Similarly, salinity reduces yield and yield components of Teff varieties at actual field experiment. Thus, based on the analysis results at different screening stages, Kora and DZ-01-974 had average maximum values of yield and yield attributes in all investigated parameters and hence, selected as promising varieties to tolerate saline environments. Accordingly, Kora and DZ01-974 were recommended for yield and yield attributes maximization. Therefore, these varieties should be validated and demonstrated to more numbers of farmers in larger plots so as to recommend to extension and end users in the district.
\end{abstract}

Keywords: Teff, Salinity, $\mathrm{NaCl}$, Growth parameters, Yield attributes

DOI: $10.7176 /$ JNSR/9-3-07

\section{Introduction}

Soil salinity is an increasing problem in the world and main obstacle to agricultural productivity especially in areas where irrigation is necessary (Flower, 2004). The increasing distribution of salt affected soil in all continents minimizes the productivity of soil resources. There is extensive salt affected soil area on all the continents. In accordance with their extent and distribution globally, a number of researchers (Heluf, 1995; Mesfin, 1980; Heluf and Mishra, 2005) have reported the wide-spread occurrence of salt affected soils in the arid and semiarid zones of Ethiopia. The total land area covered by salt affected soils in Ethiopia is estimated at about 11,033,000 hectares and occur for the most part of the rift valley zone and nowadays, soil salinity has become important problem in soils of Ethiopia (Mohamed and Tessema, 2013).

Plant species differ in their salt tolerance depending on their genetic makeup ranging from high to low levels of salts in the soil. Higher salinity level retards seed germination and root emergence due to osmotic effect, which is deleterious and prevents the plant in maintaining their proper nutritional requirements necessary for their healthy growth (Hamid et al., 2008). Plant growth is detrimentally affected by salinity as a result of the disruption of certain physiological processes that lead to reductions in yield quality. Growth, yield, and quality reduction may occur through a decrease in the ability of plants to take up water from the soil solution and the destruction of soil structure due to the presence of $\mathrm{Na}^{+}$(Krishnamurthy et al., 2007). Some elements, such as $\mathrm{Na}$ and $\mathrm{Cl}$ have specific toxic effects on plants. Salinity also causes ion toxicity, osmotic stress, mineral deficiencies which adversely affect photosynthetic, physiological and biochemical processes limiting crop yield and production to various levels (Krishnamurthy et al., 2007; Hamid et al., 2008). Salinity effects are the results of complex interactions among morphological, physiological, and biochemical processes including seed germination, plant growth, and water and nutrient uptake (Singh et al., 2013).

Teff is the major Ethiopian cereal and serving as staple food grain. The major constraints in Ethiopia's teff husbandry are low productivity (national average about $15.75 \mathrm{qt} \mathrm{ha}^{-1}$ ) and susceptibility to lodging. Teff is also a resilient crop adapted to diverse agro-ecologies with reasonable tolerance to both low (especially terminal drought) and high (waterlogging) moisture stresses. Teff therefore, is useful as a low-risk crop to farmers due to its high potential of adaption to climate change and fluctuating environmental conditions (CSA, 2015). Teff is the dominant crop next to sorghum in the cultivated lands of the district (IPMS-ILRI, 2005).

Germination and emergence stages might be useful criteria to evaluate the effect of salinity (Krishnamurthy et al., 2007). However, laboratory experiments may not be always an efficient approach under saline conditions because field salinity is present spots (Ashraf et al., 2006). In contrast, Ashraf et al., (2005) found a significant relationship between field and laboratory experiments. In fact, the variation of whole plant growth response is the best source to provide information to identify the salinity tolerant genotypes (Khan \& Ashraf, 1990). The objectives of this study were to evaluate and identify salinity stress tolerant teff varieties/lines and to determine the effect of salinity on teff varieties/lines at different levels of $\mathrm{NaCl}$. 


\section{Materials and Methods \\ Description of the district}

The study was conducted in Raya Alamata district, northern Ethiopia. The district is located at $600 \mathrm{~km}$ north of Addis Ababa and geographically located between $12^{\circ} 25^{\prime}$ and $12^{\circ} 55^{\prime}$ North latitudes and $39^{\circ} 33^{\prime}$ and $39^{\circ} 53^{\prime}$ East longitudes with an elevation of 1520 meter above sea level (REST, 1998). The landform of the district is largely level plain where Vertisols and Fluvisols are the dominant and found extensively in farmlands (Amanuel et al., 2015). The district has a bimodal rainfall pattern, though diminishing from time to time. The annual rainfall ( $\mathrm{mm})$, minimum and maximum temperatures $\left(\mathrm{O}_{\mathrm{C}}\right)$ collected from National Meteorology Service Agency show that it is $663.12,14.70$ and 28.17, respectively (REST, 1996).

Teff varieties/lines were collected from available sources and screened under saline environment for their salinity tolerance. The activity involves screening at germination, seedling and finally at actual field condition as detailed below;-

Germination stage screening: initially, adequate number of seeds (20 seeds/Petri plates) of each Teff varieties/lines were placed at 0 and $15 \mathrm{dS} \mathrm{m}^{-1}$ of $\mathrm{NaCl}$ level to screened 42 varieties/lines of Teff. On the basis of their performance for total germination percentage and germination stress index, 7 better performing varieties/lines were selected in the first stage of germination and advanced to second germination stage of screening. Accordingly, three treatments; control $\left(0 \mathrm{dS} \mathrm{m} \mathrm{m}^{-1}\right)$ and two salinity levels $\left(10\right.$ and $\left.15 \mathrm{dS} \mathrm{m}^{-1}\right)$ of saline solutions were prepared and arranged in completely randomized design (CRD) with three replications.

Total germination percentage (TGP) was calculated based on the equation; GP = (total germinated seed/ total number of seed)*100 (Ashraf and Foolad, 2005). Mean germination time (MGT) was calculated according to Ellis and Roberts (1981); MGT $=\Sigma \mathrm{dn} / \Sigma \mathrm{n}$ where, (n) is the number of seeds germinated on day d, and d is the number of days counted from the beginning of germination. Germination stress tolerance index (Ashraf et al., 2008) was calculated as; GSTI = (germination of stressed seeds / germination of control seeds) ${ }^{*} 100$.

Seedling stage screening: seedling stage screening was conducted under small lath house condition. Treatments include two factors; Teff varieties/lines and $\mathrm{NaCl}$ levels. Bulk surface soil (non -saline and non -alkaline) was collected and packed into pot. The amount of $\mathrm{NaCl}$ to be added in to dry soil was calculated using the formula (Tekalign et al., 1996):

Gram salt per 100 gm dry soil $=\left(0.064 \mathrm{dS} \mathrm{m}^{-1} X\right.$ water saturation $\left.\%\right) / 100 \%$

Accordingly, two salinity levels $\left(10\right.$ and $\left.15 \mathrm{dS} \mathrm{m}^{-1}\right)$ were prepared from a salt of $\mathrm{NaCl}$ by weighing 14.80 and $21.59 \mathrm{gm}$ of $\mathrm{NaCl}$ respectively and mixing into $6 \mathrm{~kg}$ soil packed per pot to produce 10 , and $15 \mathrm{dS} \mathrm{m}^{-1}$ salinity treatments. Treatments were arranged in completely randomized design with three replications. Seven Teff seeds of each selected varieties/lines were planted per pot. Then prepared saline solutions was added to each pot containing respective teff while maintaining the soil moisture at field capacity. Once saline treatments are added, non-saline water was used for subsequent irrigations and was applied at 5 day interval maintaining to a field capacity. Emerged seedlings were counted at 5, 7 and 9 days after planting. After the last count has been made, only 4 seedlings were maintained per pot. After 40 days of the experiment, shoot and root dry and fresh weights were calculated after dried at $70^{\circ} \mathrm{c}$ for 24 hours.

Field experiments: screening for salt tolerance and evaluation for yield and yield component performance at field condition was undertaken at salt affected area of the district. A plot size of $3 \mathrm{~m} \mathrm{X} 3 \mathrm{~m}$ with Latin square design was used. At field experiment screening stage, selected sorghum varieties were sown over two consecutive cropping seasons.

Data analysis: the collected data were subjected to the analysis of variance (ANOVA) using SAS computer package. Mean separation was carried out using least significance difference (LSD) test at 5\% probability level.

\section{Results and Discussions}

\section{Germination stage screening results}

Total germination percentage: total germination percentage (TGP) of Teff varieties were significantly reduced by the application of levels of saline solution. Abida et al,. 2012, also reported that, TGP of varieties were significantly affected by the application of levels of salinity. The analysis result also showed that, all Teff varieties were decreased in TGP with increasing salt stresses levels. However, there is no significant difference between the varieties/lines in salinity levels of $\mathrm{NaCl}$ (Table 1). 
Table 1. Total germination percentage of Teff varieties

\begin{tabular}{|c|c|c|c|c|c|c|c|}
\hline \multirow[t]{2}{*}{ Teff varieties } & \multicolumn{3}{|c|}{$\mathrm{NaCl}$ salt levels $\left(\mathrm{dS} \mathrm{m}^{-1}\right)$} & \multirow[b]{2}{*}{ Means } & \multirow[b]{2}{*}{$\operatorname{LSD}(p \leq 0.05)$} & \multirow[b]{2}{*}{$\mathrm{CV}(\%)$} & \multirow[b]{2}{*}{ Ranking } \\
\hline & 0 & 10 & 15 & & & & \\
\hline Qunco & 78.24 & 60.35 & 52.28 & 63.62 & 3.56 & 9.78 & 3 \\
\hline Magna & 75.15 & 62.23 & 50.50 & 62.63 & 4.12 & 11.85 & 4 \\
\hline Kora & 80.86 & 68.41 & 55.69 & 68.32 & 5.32 & 10.21 & 1 \\
\hline DZ-01-974 & 81.87 & 65.79 & 53.12 & 66.93 & 0.94 & 6.53 & 2 \\
\hline DZ-Cr-44 & 70.84 & 57.67 & 48.36 & 58.96 & & & 5 \\
\hline Zezew & 68.32 & 52.97 & 50.13 & 57.14 & & & 6 \\
\hline Asgori & 70.57 & 52.00 & 48.27 & 56.95 & & & 7 \\
\hline Means & 75.12 & 59.92 & 51.19 & NS & 5.94 & 15.62 & \\
\hline
\end{tabular}

At columns $\mathrm{NS}=$ not significantly different (varieties*varieties) at $\mathrm{P}<0.05$ and at rows significantly different (varieties*treatments) at $\mathrm{p}<0.05, \mathrm{LSD}=$ least significant difference; $\mathrm{CV}=$ Coefficient of variation.

The maximum TGP at the highest level of $\mathrm{NaCl}\left(15 \mathrm{dS} \mathrm{m}^{-1}\right)$ was observed in Kora (55.69\%), DZ-01-974 (53.12\%), Quncho (52.28\%) and Magna (50.50\%) respectively. The overall ranking of Teff varieties on the basis of TGP indicated that ,Kora, DZ-01-974, Quncho and Magna respectively were medium tolerant, whereas, the others were sensitive to saline environment.

Germination stress tolerance index: the two ways of ANOVA for both varieties and levels of $\mathrm{NaCl}$ with respect to GSTI was found to be significant at $(\mathrm{p}<0.05)$. The reduction was observed particularly at the highest level of salt stress $\left(15 \mathrm{dS} \mathrm{m}^{-1}\right)$. The maximum GSTI at the maximum level of Nacl was recorded in Kora, DZ-01-974, Quncho and Magna respectively. The highest GSTI under all salinity levels was noted for Kora, which was closely followed by DZ-01-974, Quncho and Magna Teff varieties (Table 2).

Table 2. Germination Stress Tolerance Index of Teff varieties

\begin{tabular}{lccclll}
\hline Teff & \multicolumn{2}{c}{$\mathrm{NaCl}$ salt levels $\left(\mathrm{dS} \mathrm{m}^{-1}\right)$} & & & & \\
Varieties & 10 & 15 & Means & LSD $(\mathrm{p} \leq 0.05)$ & CV $(\%)$ & Ranking \\
\hline Qunco & 70.50 & 60.68 & 65.59 & 2.56 & 19.01 & 3 \\
Magna & 65.36 & 52.70 & 59.03 & 4.86 & 10.85 & 4 \\
Kora & 81.85 & 68.52 & 75.19 & 5.32 & 12.54 & 1 \\
DZ-01-974 & 74.59 & 63.12 & 68.86 & 3.45 & 7.59 & 2 \\
DZ-Cr-44 & 63.65 & 47.89 & 55.77 & & 5 \\
Zezew & 57.62 & 45.36 & 51.49 & & & 6 \\
Asgori & 53.24 & 41.95 & 47.60 & & 12.62 & 7 \\
\hline Means & 66.69 & 54.32 & & 6.34 & & 5 \\
\hline
\end{tabular}

At columns (varieties*varieties) and rows (varieties*treatments) significantly different at $\mathrm{p}<0.05, \mathrm{LSD}=$ least significant difference; $\mathrm{CV}=$ Coefficient of variation

\section{Mean germination time}

The analysis results of mean germination time (MGT) revealed that, increased salinity levels of Nacl significantly delayed mean germination time in all varieties. The two ways ANOVA implied that, varieties to levels of $\mathrm{NaCl}$ with respect to MGT was found to be significant at $(\mathrm{p}<0.05)$. However, there is no significant difference between the varieties with respect to MGT in $\mathrm{NaCl}$ levels. The highest MGT (9.27 days) of Teff varieties was observed at $15 \mathrm{dS} \mathrm{m}^{-1}$ of $\mathrm{NaCl}$ while, the lowest (5.56 days) was recorded at $0 \mathrm{dS} \mathrm{m}^{-1}$ of $\mathrm{NaCl}$ (Table 3). This revealed that, more saline environment MGT of Teff varieties. This is supported by Abida et al,. (2012), who reported MGT of varieties were significantly affected by the application of increased levels of salinity.

Table 3. Mean Germination Time (in days) of Teff varieties

\begin{tabular}{llllllll}
\hline Teff & \multicolumn{3}{c}{$\mathrm{NaCl}$ salt levels $\left(\mathrm{dS} \mathrm{m} \mathrm{m}^{-1}\right)$} & & & \\
\cline { 2 - 4 } Varieties & 0 & 10 & 15 & Means & LSD $(\mathrm{p} \leq 0.05)$ & CV $(\%)$ & Ranking \\
\hline Qunco & 6.24 & 6.74 & 8.28 & 7.09 & 5.66 & 11.08 & 3 \\
Magna & 6.38 & 7.53 & 8.72 & 7.54 & 4.82 & 9.85 & 4 \\
Kora & 5.56 & 6.52 & 7.07 & 6.38 & 8.02 & 10.84 & 1 \\
DZ-01-974 & 5.87 & 6.79 & 7.59 & 6.75 & 2.84 & 8.53 & 2 \\
DZ-Cr-44 & 6.74 & 7.80 & 8.83 & 7.79 & & 5 \\
Zezew & 6.51 & 7.97 & 9.07 & 7.85 & & 6 \\
Asgori & 6.57 & 8.00 & 9.27 & 7.95 & & 15.05 & 7 \\
\hline Means & 6.27 & 7.34 & 8.40 & & 9.04 & & 5 \\
\hline
\end{tabular}

At columns NS $=$ not significantly different from each other (varieties*varieties) at $\mathrm{P}<0.05$ and at rows significantly different (varieties*treatments) at $\mathrm{p}<0.05, \mathrm{LSD}=$ least significant difference; $\mathrm{CV}=$ Coefficient of variation.

Based on the analysis result of TGP, GSTI and MGT of the Teff varieties evaluated at the second germination 
stage screening, five (5) better performing varieties; Kora, DZ-01-974 3, Quncho, Magna and DZ-Cr-44 respectively were selected and advanced to seedling stage screening.

\section{Seedling stage screening results}

\section{Plant height, shoot fresh and dry weight of Teff varieties}

The analysis results revealed that, increasing salinity levels of Nacl significantly decreased in plant height and shoot fresh weight of all Teff varieties. Similarly, there is significant difference between the varieties in plant height and shoot fresh weight whereas, there is no significant difference between varieties and the increased levels of $\mathrm{NaCl}$ with respect to shoot dry weight (Table 4).

The maximum values for plant height, shoot fresh and dry weight of all Teff varieties was recorded at control $\left(0 \mathrm{dS} \mathrm{m}^{-1}\right)$ and the minimum values was recorded at the maximum value $\left(15 \mathrm{dSm}^{-1}\right)$ of salt concentration. Accordingly, the overall ranking of Teff varieties on the basis of plant height, shoot fresh and dry weight of Teff varieties, Kora, DZ-01-974, Quncho and Magna respectively were medium tolerant whereas, the others were sensitive to saline environment.

Table 4. The effects of $\mathrm{NaCl}$ on plant height, shoot fresh and dry weight of Teff varieties.

\begin{tabular}{|c|c|c|c|c|c|c|c|c|}
\hline \multirow[t]{2}{*}{ Parameters } & \multirow{2}{*}{$\begin{array}{l}\text { Teff } \\
\text { varieties }\end{array}$} & \multicolumn{2}{|c|}{$\mathrm{NaCl}$ salt level } & \multirow[b]{2}{*}{$15 \mathrm{dS} \mathrm{m}^{-1}$} & \multirow[b]{2}{*}{ Means } & \multirow{2}{*}{$\begin{array}{l}\text { LSD } \\
(p \leq 0.05)\end{array}$} & \multirow{2}{*}{$\begin{array}{l}\mathrm{CV} \\
(\%)\end{array}$} & \multirow[t]{2}{*}{ Ranking } \\
\hline & & $0 \mathrm{dS} \mathrm{m}^{-1}$ & $10 \mathrm{dS} \mathrm{m}^{-1}$ & & & & & \\
\hline \multirow{6}{*}{$\begin{array}{l}\text { Plant height } \\
(\mathrm{Cm})\end{array}$} & Quncho & 33.64 & 27.15 & 15.82 & 25.54 & 3.19 & 13.35 & $\overline{4}$ \\
\hline & Magna & 34.78 & 28.81 & 17.38 & 26.99 & 11.54 & 16.38 & 3 \\
\hline & Kora & 40.60 & 32.30 & 23.05 & 31.98 & & & 1 \\
\hline & DZ-01-974 & 38.32 & 30.77 & 19.00 & 29.36 & 6.95 & 9.98 & 2 \\
\hline & DZ-Cr-44 & 27.21 & 18.12 & 12.39 & 19.24 & & & 5 \\
\hline & Means & 34.91 & 27.43 & 17.53 & & 8.07 & 10.54 & \\
\hline \multirow{6}{*}{$\begin{array}{l}\text { Shoot fresh } \\
\text { weight } \\
\text { (gm/pot) }\end{array}$} & Quncho & 25.01 & 24.20 & 21.51 & 23.57 & 5.15 & 12.47 & 3 \\
\hline & Magna & 24.80 & 22.23 & 21.84 & 22.96 & 4.89 & 18.10 & 4 \\
\hline & Kora & 32.73 & 27.03 & 23.98 & 27.91 & & & 1 \\
\hline & DZ-01-974 & 27.10 & 24.00 & 20.81 & 23.97 & 8.55 & 16.30 & 2 \\
\hline & DZ-Cr-44 & 22.70 & 20.12 & 19.65 & 20.82 & 2.19 & 21.75 & 5 \\
\hline & Means & 26.47 & 23.52 & 21.56 & & 7.75 & 12.86 & \\
\hline \multirow{6}{*}{$\begin{array}{l}\text { Shoot } \\
\text { weight } \\
\text { (gm/pot) }\end{array}$} & Quncho & 12.50 & 12.20 & 11.80 & 12.17 & NS & 25.18 & 4 \\
\hline & Magna & 12.82 & 12.26 & 12.00 & 12.36 & NS & 12.77 & 3 \\
\hline & Kora & 13.00 & 12.85 & 12.12 & 12.66 & & & 2 \\
\hline & DZ-01-974 & 13.10 & 13.15 & 12.52 & 12.92 & NS & 5.98 & 1 \\
\hline & DZ-Cr-44 & 12.20 & 12.00 & 11.50 & 11.90 & NS & 12.50 & 5 \\
\hline & Means & 12.72 & 12.49 & 1.99 & & NS & 10.56 & \\
\hline
\end{tabular}

At columns (varieties*varieties) and rows (varieties*treatments) significantly different at $\mathrm{p}<0.05$, LSD $=$ least significant difference; $\mathrm{CV}=$ Coefficient of variation

Root fresh and dry weight of Teff varieties

Although there is no significant difference in rows (varieties*treatments) and columns (varieties*varieties), maximum reduction of root fresh and dry matter of Teff varieties were observed at the maximum level of $\mathrm{NaCl}$ (Table 5). 
Table 5. The effects of $\mathrm{NaCl}$ salinity on root fresh and dry weight of Teff varieties.

\begin{tabular}{|c|c|c|c|c|c|c|c|c|}
\hline \multirow[t]{2}{*}{ Parameters } & \multirow{2}{*}{$\begin{array}{l}\text { Teff } \\
\text { varieties }\end{array}$} & \multicolumn{2}{|c|}{$\mathrm{NaCl}$ Salt Level } & \multirow[b]{2}{*}{$15 \mathrm{dS} \mathrm{m}^{-1}$} & \multirow[b]{2}{*}{ Means } & \multirow{2}{*}{$\begin{array}{l}\text { LSD (p } \\
\leq 0.05)\end{array}$} & \multirow{2}{*}{$\begin{array}{l}\text { CV } \\
(\%)\end{array}$} & \multirow[t]{2}{*}{ Ranking } \\
\hline & & $0 \mathrm{dS} \mathrm{m}^{-1}$ & $10 \mathrm{dS} \mathrm{m}^{-1}$ & & & & & \\
\hline \multirow{6}{*}{$\begin{array}{l}\text { Root fresh } \\
\text { weight } \\
\text { (gm/pot) }\end{array}$} & Quncho & 10.01 & 8.58 & 7.96 & 8.85 & $\mathrm{NS}$ & 10.54 & 3 \\
\hline & Magna & 9.80 & 8.28 & 7.37 & 8.48 & NS & 12.88 & 4 \\
\hline & Kora & 12.93 & 10.08 & 8.75 & 10.59 & NS & 3.94 & 1 \\
\hline & DZ-01-974 & 11.10 & 9.00 & 8.07 & 9.39 & NS & 8.17 & 2 \\
\hline & DZ-Cr-44 & 8.70 & 8.04 & 7.29 & 8.01 & NS & & 5 \\
\hline & Means & 10.50 & 8.80 & 7.79 & & NS & & \\
\hline \multirow{6}{*}{$\begin{array}{l}\text { Root dry } \\
\text { weight } \\
\text { (gm/pot) }\end{array}$} & Quncho & 6.85 & 6.20 & 5.51 & 6.19 & NS & 13.45 & 2 \\
\hline & Magna & 5.42 & 4.23 & 4.02 & 4.56 & NS & 5.87 & 4 \\
\hline & Kora & 7.45 & 6.31 & 6.12 & 6.63 & NS & 12.36 & 1 \\
\hline & DZ-01-974 & 6.10 & 5.08 & 4.81 & 5.33 & NS & 18.30 & 3 \\
\hline & DZ-Cr-44 & 5.16 & 4.12 & 3.84 & 4.37 & NS & & 5 \\
\hline & Means & 6.20 & 5.19 & 4.86 & & NS & 22.34 & \\
\hline
\end{tabular}

At columns (varieties*varieties) and rows (varieties*treatments) $\mathrm{NS}=$ non- significantly different at $\mathrm{p}<0.05, \mathrm{LSD}=$ least significant difference; $\mathrm{CV}=$ Coefficient of variation

The highest fresh and dry weight of root were observed in Kora, DZ-01-974, Quncho and Magna whereas, the lowest ones was at DZ-Cr-44. Accordingly, Teff varieties with the maximum value of fresh and dry weight of root were selected and advanced to actual field experiment screening (

\section{Field Experiment Screening Results}

First year summary: the statistical analysis showed that, there is significant difference at $(\mathrm{p} \leq 0.05)$ among the Teff varieties in days to maturity, plant height and number of tillers. Similarly, there was highly significant difference at $(p \leq 0.01)$ with in the varieties with respect to grain yield. However, there is no significance difference among the varieties in days to heading, days to emergency, panicle length and biomass yield.

Table 6. Mean values of first year yield and yield components of Teff varieties.

\begin{tabular}{|c|c|c|c|c|c|c|c|c|}
\hline Teff varieties & $\mathrm{DE}(50 \%)$ & $\mathrm{DH}(50 \%)$ & $\operatorname{DM}(50 \%)$ & $\mathrm{Ph}(\mathrm{cm})$ & $\mathrm{Nt}$ & $\mathrm{Pl}(\mathrm{cm})$ & By (qt/ha) & Gy (qt/ha) \\
\hline Qunco & 5.01 & 50.15 & 81.00 & 83.07 & 6.04 & 28.32 & 59.87 & 21.12 \\
\hline Magna & 5.08 & 51.03 & 83.21 & 80.27 & 5.52 & 28.24 & 57.69 & 19.00 \\
\hline Kora & 5.12 & 49.72 & 81.15 & 87.02 & 7.28 & 31.20 & 66.01 & 23.03 \\
\hline DZ-01-974 & 6.04 & 49.47 & 82.34 & 80.51 & 6.53 & 29.34 & 60.25 & 21.01 \\
\hline $\operatorname{LSD}(\mathrm{p} \leq 0.05)$ & $\mathrm{NS}$ & $\mathrm{NS}$ & 6.54 & 12.38 & 2.45 & NS & NS & $3.67^{* *}$ \\
\hline $\mathrm{CV}(\%)$ & 7.18 & 2.35 & 1.1 & 1.96 & 11.31 & 6.39 & 7.55 & 3.48 \\
\hline
\end{tabular}

$\mathrm{DE}(50 \%)=$ Days to 50\% Emergency; $\mathrm{DH}(50 \%)=$ Days to heading; $\mathrm{DM}(50 \%)=$ Days to maturity; $\mathrm{Ph}=\mathrm{Plant}$ height; $\mathrm{Nt}=$ Number of tillers; $\mathrm{Pl}=$ Panicle length; $\mathrm{By}=$ biomass yield; $\mathrm{Gy}=$ Grain yield; $\mathrm{LSD}=$ Least significant difference; $\mathrm{NS}=$ non-significant; $\mathrm{CV}=$ coefficient of variance; ${ }^{* *}=$ highly significant at $\operatorname{LSD}(\mathrm{p} \leq 0.01)$

Among the varieties with regard to grain yield, Kora (23.03 qt ha-1) closely followed by Qunco (21.12 $\mathrm{qt} \mathrm{ha}^{-}$ ${ }^{1}$ ) and DZ-01-974 (21.01 qt ha-1) were dominant (Table 6). With regards to yield and yield components of Teff varieties, Kora and DZ-01-974 had strong effect in all parameters in the salt affected areas. Both Kora and DZ0-974 Teff varieties were more yielded than the national average (15.75 $\left.\mathrm{qt} \mathrm{ha}^{-1}\right)$ with respect to grain yield in the first year of cropping season (CSA, 2015).

Second year summary: the statistical analysis of the varieties showed non-significant difference almost in all parameters eventhough, there was highly significant difference $(\mathrm{p} \leq 0.01)$ with respect to biomass and grain yield. Among the Teff varieties with regard to grain yield and biomass yield, Kora (22.50 qt ha-1) and (63.25 qt ha-1) followed by DZ-01-974 (19.25 qt ha-1) and (59.75 qt ha-1) respectively were superior over the other Teff varieties. Both Kora and DZ- 0-974 Teff varieties were more yielded than that of the national average (15.75 qt ha-1 $)$ with respect to grain yield in the second year of cropping season (CSA, 2015). Therefore, Kora and DZ-01-974 had average maximum values and hence, considered as salt tolerant as indicated in all parameters particularly, for the second year cropping season (Table 7). 
Table 7. Mean values of second year yield and yield components of Teff varieties.

\begin{tabular}{|c|c|c|c|c|c|c|c|c|}
\hline Teff varieties & $\mathrm{DE}(50 \%)$ & $\mathrm{HD}(50 \%)$ & $\mathrm{MD}(50 \%)$ & $\mathrm{Ph}(\mathrm{cm})$ & $\mathrm{Nt}$ & $\mathrm{Pl}(\mathrm{cm})$ & By (qt/ha) & Gy (qt/ha) \\
\hline Qunco & 6.04 & 48.14 & 81.00 & 91.18 & 5.09 & 31.18 & 56.75 & 17.50 \\
\hline Magna & 5.17 & 49.25 & 81.12 & 86.85 & 4.00 & 29.45 & 54.00 & 14.75 \\
\hline Kora & 7.57 & 48.34 & 81.23 & 100.06 & 6.15 & 33.26 & 63.25 & 22.50 \\
\hline DZ-01-974 & 6.12 & 49.10 & 82.08 & 92.47 & 5.64 & 28.27 & 59.75 & 19.25 \\
\hline $\operatorname{LSD}(\mathrm{p} \leq 0.05)$ & 10.23 & $\mathrm{NS}$ & $\mathrm{NS}$ & $\mathrm{NS}$ & $\mathrm{NS}$ & $\mathrm{NS}$ & $5.61^{* *}$ & $2.19^{* *}$ \\
\hline CV (\%) & 7.86 & 4.85 & 2.13 & 13.0 & 21.31 & 10.9 & 2.64 & 6.11 \\
\hline
\end{tabular}

$\mathrm{DE}(50 \%)=$ Days to $50 \%$ Emergency; HD $(50 \%)=$ Days to heading; $\mathrm{MD}(510 \%)=$ Days to maturity; $\mathrm{Ph}=\mathrm{Plant}$ height; $\mathrm{Nt}=$ Number of tillers; $\mathrm{Pl}=$ Panicle length; $\mathrm{By}=$ biomass yield; $\mathrm{Gy}=\mathrm{Grain}$ yield; $\mathrm{LSD}=$ Least significant difference; $\mathrm{NS}=$ non-significant; $\mathrm{CV}=$ coefficient of variance; ${ }^{* *}=$ highly significant at $\mathrm{LSD}(\mathrm{p} \leq 0.01)$.

\section{Combined analysis result of Teff varieties}

The combined analysis results of Teff varieties revealed that, statistically there is non-significant difference at ( $p$ $\leq 0.05)$ almost in all parameters even though, biomass and grain yield were found to be highly significant at $(\mathrm{p} \leq$ 0.01). Among the Teff varieties with regard to grain yield and biomass yield, Kora (22.77 $\left.\mathrm{qt} \mathrm{ha}^{-1}\right)$ and $(64.63 \mathrm{qt}$ $\left.\mathrm{ha}^{-1}\right)$ followed by DZ-01-974 (20.13 $\left.\mathrm{qt} \mathrm{ha}^{-1}\right)$ and (60.00 qt ha-1) respectively were superior over the other Teff varieties. Both Kora and DZ- 0-974 Teff varieties were more yielded than the national average (15.75 qt ha-1) with respect to grain yield in the two consecutive cropping seasons (CSA, 2015). Accordingly, Kora and DZ-01-974 had average maximum values and hence, considered as salt tolerant varieties for yield and yield components (Table 7). This revealed that, Kora and DZ-01-974 varieties showed consistent results in the first and second year of cropping season and selected as promising varieties to tolerate saline environment. Therefore, Kora and DZ-01974 Teff varieties were recommended for yield and yield component maximization in Raya Alamata district. Table 8. Combined mean values of yield and yield components of Teff varieties.

\begin{tabular}{|c|c|c|c|c|c|c|c|c|}
\hline Teff varieties & $\mathrm{DE}(50 \%)$ & $\mathrm{HD}(50 \%)$ & $\mathrm{MD}(50 \%)$ & $\mathrm{Ph}(\mathrm{cm})$ & $\mathrm{Nt}$ & $\mathrm{Pl}(\mathrm{cm})$ & By (qt/ha) & Gy (qt/ha) \\
\hline Qunco & 5.17 & 49.27 & 81.21 & 87.00 & 6.28 & 30 & 58.31 & 19.31 \\
\hline Magna & 5.84 & 50.05 & 82.16 & 83.27 & 5.25 & 29 & 55.85 & 16.88 \\
\hline Kora & 6.31 & 49.19 & 81.52 & 94.41 & 7.34 & 32 & 64.63 & 22.77 \\
\hline DZ-01-974 & 6.21 & 49.24 & 82.24 & 86.35 & 6.31 & 29 & 60.00 & 20.13 \\
\hline $\operatorname{LSD}(\mathrm{p} \leq 0.05)$ & $\mathrm{NS}$ & $\mathrm{NS}$ & $\mathrm{NS}$ & 0.87 & $\mathrm{NS}$ & $\mathrm{NS}$ & $7.54 * *$ & $2.07^{* *}$ \\
\hline $\mathrm{CV}(\%)$ & 9.03 & 1.85 & 2.52 & 2.41 & 8.48 & 6.39 & 6.75 & 2.25 \\
\hline
\end{tabular}

$\mathrm{DE}(50 \%)=$ Days to $50 \%$ Emergency; HD $(50 \%)=$ Days to heading; $\mathrm{MD}(510 \%)=$ Days to maturity; $\mathrm{Ph}=\mathrm{Plant}$ height; $\mathrm{Nt}=$ Number of tillers; $\mathrm{Pl}=$ Panicle length; $\mathrm{By}=$ biomass yield; $\mathrm{Gy}=\mathrm{Grain}$ yield; $\mathrm{LSD}=$ Least significant difference; $\mathrm{NS}=$ non-significant; $\mathrm{CV}=$ coefficient of variance $;{ }^{* *}=$ highly significant at $\mathrm{LSD}(\mathrm{p} \leq 0.01)$

\section{Conclusion and Recommendation}

Soil salinity is an increasing problem in the world and main obstacle to agricultural productivity. The increasing distribution of salt affected soil in all continents minimizes the productivity of soil resources. Therefore, developing a strategy for salt tolerant crops under saline soil condition to attain food self-sufficiency and reverse ecological degradation for agricultural sector is mandatory. Accordingly, for the last three years; screening of Teff varieties/lines for salt tolerance were conducted at three growth stages; germination, seedling and actual field experiment at laboratory, lath house and field condition respectively through exposing to salt stress condition at Raya Alamata district and come up with consistent and conclusive results.

It is concluded that salinity reduces growth parameters like fresh and dry weights of roots and shoots which are inversely related to increasing levels of $\mathrm{NaCl}$. Thus, based on the analysis results at different growth stages and consistent results, Kora and DZ-01-974 had average maximum values of yield and yield attributes and hence, considered as salt tolerant verities in all parameters. Both Kora and DZ-01-974 were more yielded than the national average $\left(15.75 \mathrm{qt} \mathrm{ha}^{-1}\right)$ with respect to grain yield in the two consecutive cropping seasons. This designates that, Kora and DZ-01-974 Teff varieties were selected as promising varieties to tolerate saline environment particularly for the study area. Therefore, Kora and DZ-01-974 Teff varieties were recommended for yield and yield component maximization.

\section{References}

Abida, K,. Yasin, M., Iftikhar, A., Niaz, M. and Qaiser, A. 2012. Evaluation of sorghum varieties/lines for salt tolerance using physiological indices as screening tool, Pakistan Journal of botany, 44(1): 47-52.

Akber, M., M. Saleem, M.Y. Ashraf, A. Hussain, F.M. Azhar and R. Ahmed. 2009. Combining ability studies for physiological and yields traits in maize at two temperatures regimes. Pak. J. Bot., 41(4): 1817-1829. 
Ashraf, F., Hussain, J,. Akhtar, A., Ross, M. and Ebert G.. 2008. Effect of different sources and rates of nitrogen and optimal level of potassium fertilization on growth, yield and nutrient. Pakistan Journal of botany, 40(4): 1521-1531.

Ashraf,Y., Akhter, Hussain, F. and Iqbal, J. 2006. Screening of different accessions of three potential grass species from Cholistan desert for salt tolerance. Pakistan Journal of Botany,38(5): 1589-1597.

Ashraf,Y., Ashraf, M. and Sarwar, G. 2005. Response of okra to drought and salinity stress. In: Vegetables: Growing Environment and Mineral Nutrition, (Ed.): R. Dris, WLF Publisher Helsinki, Finland pp. 166-177.

CSA(Central Statistical Agency). 2015. Report on area and production of major crops, Addis Ababa, Ethiopia, volume I

Flower, T.J. 2004. Improving crop salt tolerance. J. Exp. Bot., 55: 307-319.

Gates, C.T., K.P. Haydock, P.J. Claringbold and F.M. Robins. 2009. Growth of varieties of three sorghum species at different levels of salinity. Aust. J. Exptl. Agri. Animal Husb., 6: 161-169.

Hamid, M., M.Y., Ashraf, K.U. Rehman and M. Arshad. 2008. Influence of salicylic acid seed priming on growth and some biochemical attributes on wheat growth under saline conditions. Pakistan Journal of Botany, 40(1): 361-367.

Heluf Gebrekidan and B.B. Mishra, 2005. Salt Affected Soils of Middle Awash River Basin of Ethiopia: Appraisal, Characterization and Classification. Geoderma

Heluf Gebrekidan, 1995. Evaluation of the Potential Use of Langbeinite (K2SO4.2MgSO4) as a Reclaiming Material for Sodic and Saline Sodic Soils. PhD Dissertation, Graduate College, the University of Arizona, USA. $166 \mathrm{p}$.

IPMS-ILRI (Improved Productivity and Market Success-International Livestock Research Institution). 2005. Alamata pilot learning site diagnosis and program design, Tigray, Ethiopia.

Khan, H. and Ashraf, Y.. 1990. Effect of sodium chloride on growth and nitrogen metabolism of sorghum. Physiological Plant.,12: 233-238..

Krishnamurthy, L., R. Serraj, C.T. Hash, A.J. Dakheel and B.V.S. Reddy. 2007. Screening sorghum genotypes for salinity tolerant biomass production. Euphytica, 156: 15-24.

Mesfin Abebe, 1980. The state of soil science development for agriculture in Ethiopia. Ethiopian Journal of Agricultural Sciences 2(2): 139-149.

Mohamed Seid and Tessema Genenew . 2013. Evaluation of soil and water salinity for irrigation in North-eastern Ethiopia: Case study of Fursa small scale irrigation system in Awash River Basin. African Journal of Environmental Science, DOI:10.5897/AJEST2013.1464.

Netondo, G.W., J.C. Onyango and E. Beck. 2004. Response of growth, water relations, and ion accumulation to $\mathrm{NaCl}$ salinity. Crop Sci., 44: 797-805.

Singh, A. P. and Singh, A. R. 2013. Seasonal Changes In Physico-Chemical Attributes Of Salt Affected Habitat, Indian Journal of Science Research, 4 (1): 105-115.

Tekalign Mamo, Richter, C. and Heiligatag, B. 1996. Response of some varieties of durum wheat and teff to salt stress. African journal of crop Science, 4(4): 423-432. 